\title{
Towards Technological Rules for Designing Innovation Networks: a Dynamic Capabilities View
}

\author{
International Journal of Operations and Production Management \\ 2007, v27 (10) pp. 1069-1092
}

\author{
*Dr Palie Smart \\ Cranfield School of Applied Sciences, Cranfield University, Bedfordshire, MK43 0AL, UK \\ palie.smart@cranfield.ac.uk
}

Professor John Bessant

Tanaka Business School, Imperial College London, South Kensington, London, SW7 2AZ, UK j.bessant@imperial.ac.uk

Dr Abhishek Gupta

Cranfield School of Management, Cranfield University, Bedfordshire, MK43 0AL, UK abhishek.gupta@cranfield.ac.uk 


\title{
Towards Technological Rules for Designing Innovation Networks: a Dynamic Capabilities View
}

\begin{abstract}
Purpose - Interorganizational innovation networks are providing opportunities to exploit superior resources that reside beyond the boundary of the firm. The shifting locus of innovation and value creation away from the 'sole firm as innovator' poses important questions about the nature of resources that exist in the spaces between firms, and the capabilities needed to leverage them for competitive advantage. The purpose of this research is to produce design-oriented knowledge, for configuring interorganizational networks as a means of accessing such resources for innovation. Methodology / Approach - This exploratory investigation conflates emerging constructs and themes analytically induced from a systematic survey of 142 scholarly and practitioner articles and 45 expert interviews with senior professionals operating in the biopharmaceuticals industry. Findings and Practical Implications - The findings identify 7 theoretically and empirically grounded technological rules associated with effective interorganizational networking for innovation. They embody evidence ex post of networking theory and practice. Based on van Aken's seminal work, they comprise vital design-oriented knowledge to provide a solution architecture of viable action options for managers, a priori, to purposefully design innovation networks. Collectively these rules represent a tentative taxonomy, a means of classifying design principles, to assist managers in navigating their decision making processes. Originality/value of paper - This study demonstrates the need for explicit design-oriented knowledge for configuring interorganizational networks. Finally, the implications of the findings for strategic management theory are discussed from a Dynamic Capabilities view. The significance of a dynamic capability which addresses the renewal of network-specific resources is highlighted.
\end{abstract}

Keywords: Interorganizational Networks, Innovation, Resource-based View, Dynamic Capabilities View, Biopharmaceuticals

Paper Category: Research Paper 


\section{Introduction}

Competitive global businesses environments remain congruent with Eisenhart's (1989) notion of high velocity and D'Aveni's (1994) concept of hyper competition, in which technological innovations are frequent and potentially path breaking. Under such dynamic conditions, the effective renewal of products/services and how they are delivered are critical capabilities for many high tech industries (Bartlett and Ghoshal, 2002; Zahra and Nielsen, 2002; Lovas and Ghoshal, 2000; Markides and Geroski, 2003 and Bessant, 2003). This is a major concern for the traditional pharmaceuticals and emerging biopharmaceuticals sector where advancements in the field of genomics, proteomics, bioinformatics and biotechnology are increasingly of a discontinuous nature. Thus making the development of innovative medicines a risky and expensive process that demands organizational capabilities conducive to radical innovation.

Research is beginning to illustrate how relatively novel organizational forms such as 'networks' are being deployed to access new technologies and their associated knowhow to improve innovation capacity (George et al, 2002, Hagedoorn and Duysters, 2002). Such opportunities to exploit superior external knowledge resources often come with the promise of new products for new markets. The use of innovation networks has become a distinctive feature of the rapidly growing biopharmaceuticals sector. Liesband et al (1996) in their study of New Biotechnology Firms (NBF) consider three organizational options for sourcing scientific knowledge: internal sourcing via internal hierarchies, external sourcing through markets exchanges and external sourcing through organizational networks. Granovetter (1985) and Powell (1998) provide a critique of the traditional hierarchies and markets viewpoint in suggesting that, its use does not acknowledge the importance of the social dimension as a means of governing business exchange, which is often predicated on trust. Tidd (1995) points out that whilst the network concept appears relatively novel and able to overcome the 'market vs. hierarchies' debate, as a so-called 'third way', it is echoed in earlier research by Rumelt in the 1970s and Rothwell's (1994) Fifth Generation model of innovation. More recently, Chesbrough's notion of Open Innovation and Bessant's (2004) idea of High Involvement Innovation also replay similar generic arguments regarding the use of networks and confirm their potential to create new value. Coombs \& Metcalfe's (2002) argue that whilst the pharmaceutical sector has traditionally enjoyed considerable organic growth as a result of their patents, intellectual property, technologies, marketing and production capabilities, today's competitive environment is demanding fundamental changes to the way they do business. In particular, Coombs \& Metcalfe are intrigued by way in which these firms have avoided a reliance on external expertise in the face of new biotechnological advancements, and how in recent years this climate has forced them to combine, reconfigure, integrate and coordinate resources within what they have termed a 'distributed innovation system'.

\section{A Dynamic Capabilities View of Biopharmaceuticals Product Development}

Biopharmaceutical product development is reliant on complementary resources bestowed by different organizations in a wider network, which is often globally 
dispersed. Such networks may include universities, clinical research organizations (CRO), pharmaceuticals companies; small genomics research laboratories, independent financiers, proprietary technology providers and other new biotechnology firms (NBFs). The pooling effect of resources as an organizational level activity has been portrayed in other high tech industries (Hankasson, 1990) as a 'network approach' to innovation (Bower, 1993). Unlike other approaches (e.g. resource dependency, transaction cost and agency) it seeks to understand how the focal firm and its peripheries change the multi-player (or network) context through their interactions. Such new industry settings are shifting the locus of knowledge, learning and value creation beyond the boundary of the single firm and into the network, with important implications for its future management and organization.

The Resource Based View (RBV) of the firm is a useful theoretical framework for understanding how such dynamics lead to competitive advantage (Barney, 1991; Nelson, 1991; Penrose, 1959; Prahalad and Hamel, 1990; Teece et al, 1997). As a progressively dominant theoretical view in the field of strategic management, it concerns itself with resources as being critical to a firm's competitive advantage and long-term survival. Whilst importance is attached to all physical and organizational resources, special reference is made to knowledge and competencies based resources.

In connecting the RBV to dynamic market environments more closely, Teece et al (1997) discuss the notion of 'dynamic capabilities' through which managers 'integrate, build and reconfigure internal and external competencies to address changing environments' (Teece et al 1997). As a body of knowledge that has progressed rapidly over the last few decades it explores the nature of such capabilities, and their distinguishing characteristics. A main thrust of this literature argues that dynamic capabilities are essentially organizational routines deployed to alter a resource base by 'acquiring, creating, shedding, integrating, and recombining existing resources to generate new value creating strategies' (Pisano, 1996). Whilst the functionality of dynamics capabilities is generic and applicable across business contexts, their value lies in the resource configurations they create and not in the capabilities themselves (Eisenhardt and Martin, 2000).

Like Preim and Butler (2001) in their recent portrayal of the limitations of Barney's RBV, Eisenhardt and Martin (2000) suggest that the RBV misjudges the locus of long-term competitive advantage in dynamic markets. In considering this suggestion in the context of biopharmaceutical new product development (biopharma NPD), the prevailing industry dynamics are shifting the locus of knowledge and value creation within the supply and demand chains. Therefore it seems plausible to propose that innovation, and hence competitive advantage, cannot be simply manipulated from within the boundary of a single firm, as presumed by a traditional RBV perspective, but rather from within a network of heterogeneous firms. This poses questions concerning the nature of resources that exist in the space between firms and how they are leveraged. Such inquiries are relevant to operationalizing interorganizational innovation networks effectively, a topic which to date has witnessed a significant lack of management research to produce design-oriented knowledge. This research deploys van Aken's seminal ideas of generating design-oriented knowledge through the development of what he calls 'grounded and field-tested technological rules' (van Aken, 2005). 
This paper presents 7 empirically and theoretically grounded technological rules associated with effective interorganizational networking for innovation. These rules embody evidence ex post of networking theory and practice. In doing so, the rules compose vital design-oriented knowledge which provides solution architecture of viable action options for managers a priori, to purposefully design innovation networks. Collectively these rules represent a tentative taxonomy, a means of classifying design principles, to assist managers in navigating their decision making processes and devising appropriate network development strategies. It acts as a useful framework for evaluating current managerial practice and considering the range of possibilities available to guide future action. In doing so, it constitutes valuable transferable knowledge to support improvements in innovation capacity and performance. The investigation conflates emerging constructs and themes analytically induced from a systematic survey of 142 scholarly articles and 45 expert interviews with senior professionals in the burgeoning global biopharmaceuticals sector. The resultant synthesis is recommended for further field-testing, as an important antecedent to management action to better inform the broader practice of managing innovation in an increasingly multi-player (or network) context. The managerial implications of each rule associated with designing innovation networks are considered. Finally, the strategic management propositions of the research have been discussed from a Dynamic Capabilities view, and in particular its failure to adequately address capabilities associated with the renewal of network-specific resources.

\section{Methods}

This research adopts van Aken's (2005) eloquent diagnosis of the discipline of management as a 'design science' (similar to medicine and engineering) to be distinct from the 'explanatory' sciences (similar to physics, chemistry and biology). He suggests the science of management is primarily concerned with the need to produce design-oriented knowledge via 'grounded and field tested technological rules' based on Bunge's notion of 'technological rules' (1967). van Aken (2005) advocates the view that field testing these rules in the real world enables descriptive knowledge to be applied, and transformed into actionable design knowledge. This design knowledge provides a solution architecture composing viable action options for managers, and so an important antecedent to management practice.

As a leading researcher in the field of innovation management van Aken is a prolific supporter of research conducted within the framework of a Mode 2 knowledge production system, and 'in the context of application' (Gibbons et al, 1994; Huff, 2000; Nowotny et al, 2001). Mode 2 research is multidisciplinary and seeks to solve complex and relevant problems in the field, as distinct from Mode 1 research which is often disciplinary and drives further research enquiry, as often evident in the natural sciences.

This study upholds innovation management as a branch of management research and corroborates van Aken views that richness can be gained through combining both mode 1 and mode 2 strategies. In doing so, quantitative and qualitative data from two complementary research phases deploying Systematic Review (SR) and empirical semi-structured interviews are conflated. The resultant synthesis of 7 empirically and 
theoretically grounded technological rules is recommended for further field-testing. The following sections describe each of the research phases.

\section{Sample and Procedure}

\section{Phase 1: Systematic Review}

An extensive Systematic Review (SR) of the extant literature sought to identify key constructs influencing effective interorganizational networking practice. The SR adopts an evidenced based approach to assimilating secondary data using peer review and formalized criteria, based on its principal use in the medical field. It has a defined protocol designed to provide a transparency and auditability based on Tranfield et al (2003) as follows:

- An initial investigation of the ABI Proquest database was undertaken through search strings using the keywords in table 1 . This as conducted within a select list of international scholarly and practitioner journals in the management science field. The search resulted in a total of more than 1500 articles, from which 142 articles were selected for further review based on specific inclusion/exclusion criteria set in accordance with the research aims and objectives. A sector focus was imposed to include management research in the pharmaceuticals, biotechnology and biopharmaceuticals domains.

- A database of the included 142 articles formed an 'A' list for subsequent quantitative and qualitative analysis.

- The 'A' list was initially subject to demographic analysis to gauge deeper understanding of the nature and form of the dataset.

- Summaries of the 'A' list articles were transferred onto data recording sheets for subsequent theme based content analysis, open coding and generation of higher order themes.

- A synthesis of this extant literature led to emergence of major constructs which were subsequently conflated with phase 2 of the study.

Table 1: Systematic Review: Keywords

\begin{tabular}{|l|}
\hline \multicolumn{2}{|c|}{ 'Keywords' for search string formation } \\
\hline social capital \\
\hline innovation network \\
\hline innovation AND network \\
\hline network* AND (pharma* OR biotech*) \\
\hline Strategic alliance* AND (pharma* OR biotech*) \\
\hline Total number of articles reviewed \\
\hline
\end{tabular}

\section{Phase 2: Empirical study}

The aim of this exploratory investigation was to gain novel insights into the growing practice of interorganizational innovation. Therefore 45 semi-structured interviews with senior professionals in the biopharmaceuticals field were conducted, initially to examine major shifts in management practice regarding:

\section{- biopharma NPD over the past 20 years}


- interorganizational innovation as an explicit NPD strategy

- enablers and barriers to implementing effective interorganizational innovation

- how drug development specialists acquire new sources of knowledge

- current and future challenges facing drug development firms

- support for the future of biopharma NPD

This exploratory approach relies heavily on analytical induction which does not require probability based sampling techniques, because an important aim of the study is to generate further avenues of research inquiry (Yin, 2003). The research sample, shown in table 2, was selected using a modified 'snowballing' technique (Miles \& Huberman, 1994), whereby the initial informants were identified by the research partners, for their high profile responsibilities across organizational and disciplinary boundaries in a biopharma NPD context.

Table 2 The Sample of Respondents

\begin{tabular}{|c|c|c|c|}
\hline Type of firm & $\begin{array}{l}\text { No. of } \\
\text { firms }\end{array}$ & $\begin{array}{l}\text { No. of } \\
\text { interviews }\end{array}$ & Exemplar informants \\
\hline $\begin{array}{l}\text { Big } \\
\text { Pharmaceuticals }\end{array}$ & 4 & 12 & $\begin{array}{l}\text { Vice President Biology, Head of Bioinformatics, R\&D } \\
\text { Manager, Manager, Capacity \& Resource Planning }\end{array}$ \\
\hline Biotechnology & 3 & 10 & $\begin{array}{l}\text { Head of Drug Discovery, Vice President, Strategic } \\
\text { Alliances, Vice President Sales }\end{array}$ \\
\hline $\begin{array}{l}\text { Life Sciences } \\
\text { Consultancy }\end{array}$ & 4 & 10 & $\begin{array}{l}\text { Associate Partner, Director Pharmaceuticals R\&D, } \\
\text { Principal Managing Consultant, Group Head } \\
\text { Pharmaceuticals R\&D Europe }\end{array}$ \\
\hline $\begin{array}{l}\text { Biotechnology } \\
\text { Professional } \\
\text { Association }\end{array}$ & 2 & 4 & $\begin{array}{l}\text { CEO BioIndustry Association (UK), Director of } \\
\text { Bioprocess UK, Business Development Director, CEO } \\
\text { Regional Biotechnology Initiative }\end{array}$ \\
\hline $\begin{array}{l}\text { Academic } \\
\text { Institutions }\end{array}$ & 6 & 9 & Professor, Senior Lecturer, Senior Researchers \\
\hline Total & 19 & 45 & \\
\hline
\end{tabular}

The interviews ranged from between 45 minutes to 3 hours in duration, and where possible tape recorded for subsequent transcription. In the small number of cases where consent for tape recording was not forthcoming, detailed notes were made during and after the interview. The transcriptions and notes generated a substantial dataset for qualitative analysis. A process of analytical induction using Theme Based Content Analysis (TBCA) revealed 6 second order themes induced from 34 first order open codes. Generic themes materialized through the expansion and contraction of key constructs, based on coding instances within the personalized accounts of interviewees, which further refined the clustering process. In addition to this, corporate documentation and other archival records were also included for analysis where available.

\section{Findings}

\section{Phase 1: Systematic Review}

The Systematic Review (SR) protocol identified 10 key constructs influencing effective interorganizational networking practice for innovation, from the extant 
literature. Table 3 incorporates these constructs as a theoretical framework, and the outcome of a process of qualitative induction. Each of these constructs is briefly discussed in the following sections and subsequently conflated with the findings of the empirical study.

The full 'A' list of 142 articles shows a relatively even split of European, UK and US published items. Furthermore 102 of these items were empirically based, 15 presented explicit design guidance in relation to innovation networks and whilst 77 upheld a strong knowledge based view, only 10 discussed the research findings from a Dynamic Capabilities view.

Table 3: Theoretical framework

\begin{tabular}{|l|r|r|}
\hline $\begin{array}{c}\text { Key constructs influencing effective interorganizational networking } \\
\text { practice for innovation }\end{array}$ & $\begin{array}{c}\text { Number of } \\
\text { citations }\end{array}$ & $\begin{array}{c}\text { Percentage } \\
\%\end{array}$ \\
\hline Dynamic view & 14 & 4 \\
\hline Process and structure & 63 & 16 \\
\hline Unintended consequences & 20 & 5 \\
\hline Heterogeneity & 48 & 12 \\
\hline Openness and security & 44 & 11 \\
\hline Connectivity & 52 & 13 \\
\hline Learning and knowledge transfer & 43 & 11 \\
\hline Relationship management & 49 & 13 \\
\hline Continuous and discontinuous renewal & 30 & 8 \\
\hline Complexity and embeddedness & 26 & 7 \\
\hline
\end{tabular}

\section{Dynamic view}

A significant proportion of the literature discusses the use of networks and learning from a dynamic view that illustrates the changing nature of organizational ties over time. Networks are considered from an evolutionary life cycle perspective with different phases of development which happen over a period of time (Pyka \& Saviotti, 2001; Kreiner \& Schultz, 1993). For example, there is usually an initiation phase, growth phase, stability phase and then a maturity phase, whereby the network might spur new connections or perhaps the existing connections might become dormant, only to be rejuvenated with a change in context at a later point in time. The dimension of time acknowledges that whilst a network may have a life span, individual connections are not necessarily product or network development phasespecific and will eventually develop their own history and path dependencies (Orsenigo et al, 2001 and Powell et al, 1996). Learning in networks is enhanced due to firm's increased opportunities to access new sources of knowledge through a variety of external linkages. Therefore networked firms are conducive to developing their capacity to absorb knowledge from external sources (i.e. absorptive capacity) and organizational routines for doing so (i.e. collaborative capacity).

\section{Structure and process}

The outcomes of network organizational arrangements can be enhanced, if both the wider network and specific network connections are actively managed and structured from initial inception to end-of-life (Pittaway et al, 2004). Whilst an active management approach engenders formality, it is prudent to overtly facilitate the conditions conducive to releasing the potential benefits often associated with the 
informal nature of networks. For example, Bessant et al (2001) in their study of supply, innovation and learning networks articulate a framework of 8 generic processes for actively managing network dynamics based on the work by Gandori and Soda (1995). These include network creation, decision-making, conflict resolution, information processing, knowledge capture, integration, risk/benefit sharing as explicit processes to be managed.

\section{Unintended consequences}

Networks have emergent properties and creating conditions to foster serendipity can be advantageous in achieving both intended and non-intended outcomes. A good start might be to positively encourage social networking through planned attendances at various business conferences, industry forums etc., with a view of using this platform to promote formal partnering (Kreiner \& Schultz, 1993). It is important to realize that the foundation of effective networks will also emerge informally over time, but then a repertoire of processes need to be undertaken which follows an incremental and sequential transition from loose conversations and discussions to defined contractual obligations (Powell, 1998; Oliver \& Liebeskind, 1998). Managers in their role as 'network architects' must recognize that there are opportunities to capitalize upon the emergent properties of network dynamics. This may require significant investments in time and other resources to build professional trust, respect and loyalty amongst various networked firms, with a view to this being a sound basis for future exchange.

\section{Heterogeneity}

Organizational networks in the biopharmaceuticals sector are becoming diverse as firms recognize that future sources of innovation lie beyond the boundary of the firm. Network building strategies are being shaped by the increasing specialisation and fragmentation of scientific and technological knowledge in this sector's quest for complementarities and synergies between the offerings of different firms. This is of course leading to greater dependencies and integration of disciplines across firm boundaries in an interactive innovation system (Swan et al, 2004). Diverse inputs from within the network contribute towards creative exploration and the effective exploitation of ideas, which subsequently improve the outcomes achieved for the amount of resources invested (Oliver, 2004; Murray, 2004; Powell et al, 1996). One way to achieve heterogeneity within a network is for organizations to gain preferred partner status within the sector communities (Dyer et al, 2001). Having a reputation which attracts a plentiful of partners allows firms to exercise sufficient choice in selecting collaborators, and achieve higher levels of network involvement and access to a diverse and rich knowledge base (Powell, 1998 and Florida et al, 2003).

\section{Openness and security}

Firms operating in networks may experience a level of insecurity arising from knowledge sharing activities, which carry potential risks to their IPR. The mismanagement of such tensions can impose limitations on the amount of learning that might take place amongst network partners (Owen-Smith \& Powell, 2004; Gargiulo \& Benassi, 2000). Whilst the benefits of 'openness' and reaching outside firm boundaries can not be over-emphasized (Burt, 1997; 1992), a degree of caution and 'closure' also needs to be exercised (Coleman, 1990; 1998). Consequently, networked firms will often devise mechanisms to ensure an appropriate level of security and closure, particularly if their interactions are due to exploitative activity 
e.g. memorandum of understanding, consortium agreements, legal and non-disclosure agreements, exclusive licensing contracts, version control or proprietary access etc.

\section{Connectivity}

Human connectivity that can be augmented through digital connectivity (internet and intranet) and its ancillary developments such as e-mail, file transfer protocol, user generated collaborative cyber workspaces, social networking software, video/webconferencing etc, can deliver knowledge advantages (Belussi and Arcangeli, 1998). Good connectivity or heavyweight membership of a network often results in firms occupying multiple locations in a wider network. This high involvement strategy can lead to other intangible benefits such as enhanced professional profile and reputation. In addition, it may also result in increased adjacency to multiple channels of knowledge flow, enabling swift navigation through a diverse resource base (Kostova \& Roth, 2003; Prusak \& Lesser, 1999). Such high involvement can often be a largely bridging activity across what Burt (1992) calls 'structural holes' in networks, and needs to be complemented with sufficient bonding level activity to foster communities of practice $(\mathrm{CoP})$. This process of communalization will embed social structures in CoPs, often predicated on trust, which becomes an important coordination mechanism within interorganizational networks.

\section{Learning and knowledge transfer}

Networks can benefit from engendering a dual approach to knowledge transfer in which learning is pursued in a both responsive and proactive manner. Therefore the sharing of experiences between networked firms through the exchange of dialogue as a means of knowledge diffusion (Prusak \& Cohen, 2001; Powell, 1998) is very much encouraged. The further construction of systematic measures (for e.g. may include co-publications and co-patenting) to diffuse the learning within networks is also strongly advocated (Owen-Smith \& Powell, 2003; Murray, 2004; Orsenigo et al, 2001; Powell, 1998 and Powell et al, 1996). In doing so the network is able to endorse the view of 'learning as participation' and a kin to CoPs, as separate from the view 'learning as acquisition' (Yli-Renko, Autio \& Sapieza, 2001).

\section{Relationship management}

Networked organizations can improve innovation outcomes by increasing relational strength (Nahapiet \& Ghoshal, 1998) by promoting trust and flexibility through low levels of prescription. This for example means having shared norms, values, obligations and expectations which facilitate benevolence leading to achieving the intended outcomes (Adler \& Kwon; 2002; Bolino, Turnley \& Bloodgood; 2002). In terms of enhancing flexibility, trusting relationships encourage informal monitoring and a reduced reliance on formal governance mechanisms with high levels of prescription (Barney \& Hansen, 1994). Networks with high degree of relational strength can engender a high reliability organization with improved levels of redundancy for greater flexibility and responsiveness to changing demands (Smart et al, 2003; Newell, Tansley \& Huang, 2004).

\section{Continuous and discontinuous renewal}

Networks are not static structures and as connections continually evolve, the resource pool in the network is renewed through the multiplicity of collaborating arrangements ongoing (Cross, Borgatti \& Parker, 2002). We can deploy the term 'ambidextrous 
innovation'- the simultaneous pursuit of both incremental and discontinuous change (O'Reilly III Tushman, 2004; Tushman and O'Reilly III, 1996) to describe the need for firms in networks to be linked in a multifaceted capacity. For example, firms involved in networks to explore specific know-how must also be cognizant of the potential to exploit existing capabilities within the same or different relationship. We use the term 'Explo-ti-ring'- exploiting existing capabilities and exploring new opportunities (Uzzi \& Lancaster, 2003) to describe this phenomenon. Simple being aware of these notions allows networked firms to make more informed and strategic decisions about how to best apportion their R\&D investments.

\section{Complexity and embeddedness}

Complexity in the biopharmaceuticals sector often implies escalating advances in science and technology which demand firms to be part of a wider network to explore, understand, learn and exploit the underpinning knowledge (Owen-Smith et al, 2002; Pyka, 2002; Frenken, 2000). Another dimension to complexity is that of structural complexity, occurring due to the inevitable embeddedness and nesting of different networks, further complicated by the various path dependencies of firms (Gulati, Nohria \& Zaheer, 2000; Stevenson \& Greenberg, 2000). Essentially the key concern for networked firms is how to navigate from within these structures, the relevant learning and knowledge which has been generated (Powell, 1998). In such circumstances considering a firm's connections as a strategic portfolio of collaborations, that can be manipulated to identify knowledge and technology complementarities or synergies within a network, could be beneficial.

\section{Phase 2: Empirical study - expert semi-structured interviews}

Table 4 (see Appendix 1) presents a scattergram which summarizes the Theme Based Content Analysis (TBCA) of the 45 expert interviews, and consisted of transcripts, detailed notes, corporate documentation and other archival records. It illustrates a range of emerging themes and related sub-themes, indicative of the macro and micro level considerations informing management practices linked with interorganizational innovation.

The theoretical framework of 10 key constructs derived from the SR process was used as an analytical lens to further investigate the empirical data and conflate the studies. The resultant synthesis identified 7 theoretically and empirically grounded technological rules associated with effective interorganizational networking for innovation. They embody evidence ex post of networking theory and practice. In doing so, the rules compose vital design-oriented knowledge which provides a solution architecture of viable action options for managers a priori, to purposefully design innovation networks. The rules are presented in table 5 and further fieldtesting through application is recommended as an important antecedent to future management action. 
Table 5: Emerging Technological Rules

\begin{tabular}{|c|c|c|}
\hline $\begin{array}{l}10 \text { Constructs } \\
\text { Sys. Review }\end{array}$ & Exemplary empirical evidence & $\begin{array}{c}7 \text { Emerging } \\
\text { Rules }\end{array}$ \\
\hline Dynamic view & $\begin{array}{l}\text { - Emphasis on 'disease centeredness' and 'targeted treatments' results in holistic and long-term networks } \\
\text { - Sophisticated multi-NPD phase collaborations engage a product 'life-cycle' perspective e.g. deploying co-development, co-marketing, co-promotion, in-licence, out- } \\
\text { licence, hybrid 'out-in' licensing, strategic alliancing, merger and acquisition } \\
\text { - New business models and 'rules of engagement' favour more flexible and multi-NPD phase collaborations } \\
\text { - Venture capitalists seek evidence of commercialization networks (for e.g. manufacturing, marketing, and logistics) }\end{array}$ & $\begin{array}{l}\text { Design for } \\
\text { lifecycle }\end{array}$ \\
\hline $\begin{array}{l}\text { Structure and } \\
\text { process }\end{array}$ & $\begin{array}{l}\text { - New structures for coordinating co-NPD e.g. Office of Alliance Management } \\
\text { - Interorganizational collaborative capability considered as a core organizational competence } \\
\text { - Seeking partners with successful history of co-NPD and collaborative capability is deployed as an explicit network creation strategy } \\
\text { - Strategic management of IP intensified external scouting in specific therapeutic/geographical areas for key scientists, professors and serial entrepreneurs } \\
\text { - Quest for technological synergies and complementarities drives product innovation }\end{array}$ & $\begin{array}{l}\text { Design for } \\
\text { proactive } \\
\text { management }\end{array}$ \\
\hline $\begin{array}{l}\text { Unintended } \\
\text { consequences }\end{array}$ & $\begin{array}{l}\text { - Senior management recognize benefits resulting from the unintended outcomes of formalised networks } \\
\text { - Creating conditions for creativity and serendipity (e.g. acceptance of 'under the bench' research) } \\
\text { - Informal and formal networks spin out of existing networks in a self organizing manner }\end{array}$ & $\begin{array}{l}\text { Design for } \\
\text { emergence }\end{array}$ \\
\hline Heterogeneity & $\begin{array}{l}\text { - Splitting and outsourcing of R\&D functions forges new links with service and technology providers } \\
\text { - Diverse partners in networks symptomatic of the increased fragmentation of disciplinary knowledge and division of labour e.g. clinical research organizations, } \\
\text { incubators, knowledge brokers, NPD teams, micro-biologists, medicinal chemists, nanotechnologists, proteomics scientists, contract manufacturers, bioinformatics, } \\
\text { gene expressionists/sequencers, statisticians, computer scientists, bioinformatics, structural biology, combinatorial chemistry and high throughput screening } \\
\text { - Emerging 'Systems Biology' paradigm encourages greater multidisciplinarity }\end{array}$ & $\begin{array}{l}\text { Design for } \\
\text { diversity }\end{array}$ \\
\hline $\begin{array}{l}\text { Connectivity } \\
\text { Relationship } \\
\text { Management }\end{array}$ & $\begin{array}{l}\text { - Prolific network participation is a distinctive feature of the biopharma industry (e.g. discovery networks, developments networks, social networks, manufacturing } \\
\text { networks, IP networks, regional networks, dti mission networks, networking networks, professional networks/conference circuits) } \\
\text { - A profile and voice in the community is a valued outcome of participation in various networks } \\
\text { - Search for strategic network partners within existing networks (e.g. access into social/professional networks of serial entrepreneurs, industry veteran's and key scientists) } \\
\text { - Strategic network partners are recruited to numerous scientific boards of new start-ups }\end{array}$ & $\begin{array}{l}\text { Design for } \\
\text { high } \\
\text { involvement }\end{array}$ \\
\hline $\begin{array}{l}\text { Learning \& } \\
\text { knowledge } \\
\text { transfer }\end{array}$ & $\begin{array}{l}\text { - Adoption of knowledge management systems in interorganizational NPD teams } \\
\text { - Dedicated time to pursue personal research interests through experimentation } \\
\text { - Desire to ensure learning is not divorced from the practice of scientists } \\
\text { - Using formalised industrial networks to explore new scientific and technological discoveries } \\
\end{array}$ & $\begin{array}{l}\text { Design for } \\
\text { diffusion }\end{array}$ \\
\hline $\begin{array}{l}\text { Embeddedness } \\
\& \text { complexity } \\
\text { Openness \& } \\
\text { security } \\
\text { Continuous \& } \\
\text { discontinuous } \\
\text { renewal }\end{array}$ & $\begin{array}{l}\text { - The embeddedness and overlapping nature of different networks is widely acknowledged } \\
\text { - Portfolio project management techniques are being considered to strategically manage co-NPD collaborations. For e.g. loosely coupled contracts for exploration (with } \\
\text { low barriers to entry) and tightly coupled (high specified agreements) for exploitative (high barriers to entries) activity } \\
\text { - In licensing IP and links with key scientists for tacit knowledge of disease progression and pathology } \\
\text { - Patents expiries on some blockbusters and me-too products within next 5-10 years is encouraging prolific scouting IP for new niche product offerings } \\
\text { - Standardization e.g. electronic note book enables sharing of experience, yet increased insecurity regarding knowledge spill-overs } \\
\text { - Complexity arising from engagement in product, process technology oriented networks } \\
\text { - IP insecurity addressed through links with executive education providers for bioscience professionals }\end{array}$ & $\begin{array}{l}\text { Design for } \\
\text { strategic } \\
\text { innovation } \\
\text { portfolio }\end{array}$ \\
\hline
\end{tabular}


Overall, the research findings confirmed the chief assertions in the extant literature regarding the state of flux in the pharmaceutical industry, and the promises of the rapidly growing biopharmaceutical sector. They also confirmed the widespread aspirations and practice of interorganizational innovation, as a viable strategy for long-term competitive advantage by creating new value through the combination and exchange of knowledge resources. This is exemplified with the rising number of biotech-BigPharma collaborations and the generally well networked bioscience sector. The evidence of what constitutes effective interorganizational networking practice for innovation, signalled a disproportionate emphasis in favour of networking processes as distinct from their counterpart network structures. For example, these included processes for selecting network partners, limiting knowledge spill-over in geographical clusters, co-learning, strategic positioning in multiple networks, recognising the importance of informal social ties in facilitating collaboration and the effective management of Intellectual Property Rights (IPR).

\section{Managerial implications: technological rules and design-oriented knowledge}

Conflating the theoretical and empirical findings has identified a set of 7 grounded technological rules, associated with effective interorganizational networking for innovation. More specifically, they comprise vital design-oriented knowledge for purposefully designing the structures and processes of effective networks. Thus improving practices associated with operationalizing inter-organizational innovation networks through improved design, at both the strategic and operations management levels.

Collectively these rules represent a tentative taxonomy, a means of classifying design principles, to assist managers in navigating their decision making processes and devising appropriate network development strategies. It acts as a useful framework for evaluating current managerial practice and considering the range of possibilities available to guide future action. In essence, the managerial implications of these rules suggest that, together they provide an overall architecture for innovation management solutions at an inter-organizational level. Figure 1 illustrates a conceptualisation of the relationship between the taxonomy of rules and management action. Further fieldtesting of these tentative rules through application is recommended. The following sections briefly consider the managerial implications of each rule.

Figure 1. Conceptualising the relationship between rules and action

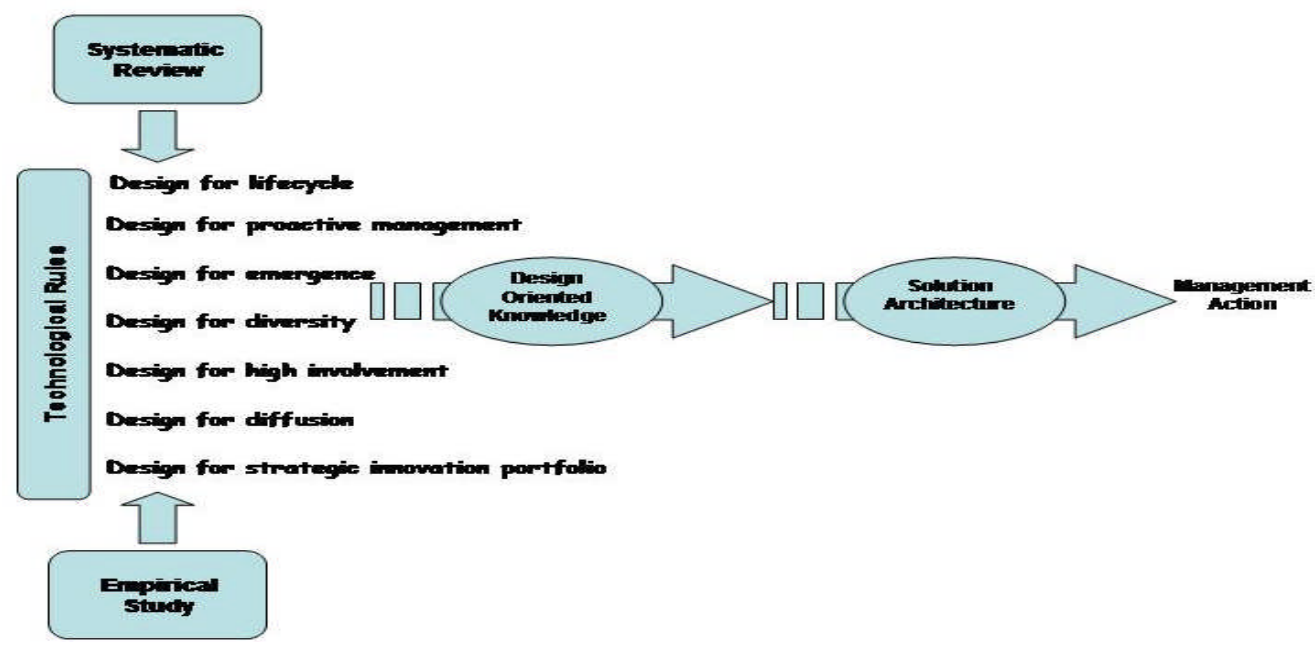


Design for lifecycle

The design for lifecycle rule conflates the theoretical construct 'dynamic perspective' and management practices associated with increasingly varied and sophisticated conew product development (co-NPD) strategies. The implication of this rule for managers is that they need to be mindful of the potential for collaborative opportunities within the entire product lifecycle during co-NPD strategy formation. Therefore, they should seek to ensure sufficient flexibility in their negotiations with potential partners to allow for multi-phased co-NPD involvement where appropriate. In other words, co-NPD strategies restricted to single phases of the NPD process i.e. (design or development) hold the risk of limiting the potential to collaborate during other downstream activities (i.e. marketing and logistics) in a more holistic and profitable manner. This approach is echoed in the following quotation:

"We went from out-licensing of everything to out-licensing in agreements and asking a bigger
piece of the pie, going through different business models, in turn developing bigger
infrastructure, capabilities and then asking later on not only to co-develop, co-market and
then became bigger ourselves." (Head of Drug Discovery, Biotech)

Design for proactive management

The design for proactive management rule conflates the theoretical construct 'structure and process' and management practices associated with the coordination of networks. For example, setting up formal structures (i.e. small departments and units) and the processes to manage external linkages with co-NPD partners is becoming increasingly common. The implication of this rule for managers is to recognize that the effective operation of networks demands a degree of proactive management. More specifically, this needs to be done with the appreciation of a generic process of network development at play (i.e. creation, operation \& closure of external linkages), if the full benefits of innovation, such as identifying complementarities and synergies for exploitation purposes are to be reaped. In the words of one of our senior professionals:

"There is an orchestrated networking program going on." (Alliance Manager, Biotech)

\section{Design for emergence}

The design for emergence rule conflates the theoretical construct 'unintended consequences' and management practices associated with creating the conditions in which creativity and serendipity are encouraged. Often this invites a recognition of the self organizing characteristics of networks. The implications of this rule for managers is to acknowledge the informal channels through which innovation and learning take place which, by their very nature, do not lend themselves to formal management controls. Valuing and harnessing this informality will enable greater scope to capitalize on the ad-hoc and emergent properties of network dynamics. This viewpoint was expressed by one of the research participants as follows:

"How you find out something is very ad hoc. Something someone says will spark something in someone else mind. We can only but try to create opportunities for serendipity." (Head of Bioinformatics, Big Pharma) 


\title{
Design for diversity
}

The design for diversity rule conflates the theoretical construct 'heterogeneity' with management practices associated with increasing the levels of diversity to enrich the NPD process. This is partially due to the separation of some research from development activities, and the generally higher levels of complexity in new products, compounding the greater fragmentation of core disciplines and specialization. The implications of this rule for managers is to encourage diversity of NPD experience, skills, and disciplines in networks to enhance the creative potential for innovation, decision making and speed to market. The significance of diversity is clearly witnessed in the following quotation:

"We want a lot of inter-disciplinarity; a lot of transferable skills. People working in R\&D should speak a diverse language. Since everyone is looking at different levels of details and different levels of complexity, there are different priorities, different scales, different magnitudes, and different parameters. It's is a very complex world." (Head of Bioinformatics, Big Pharma)

\section{Design for high involvement}

The design for high involvement rule conflates the notions of 'connectivity' and 'relationship management' and management practices associated with increasing levels of involvement of people with different backgrounds in networked NPD. Essentially;

\begin{abstract}
"[Success] It all boils down to individual relationships. The whole area of relationship management is very tough. We should never underestimate how important relationship management is, or the individuals who are required for maintaining this. It falls down to the two people at the interface - the person in charge of the liaison from the BigPharma side with the person from the biotech." (Alliance Manager, Biotech)
\end{abstract}

The implication for managers is to recognize that productive networks depend on prolific connectivity at both the structural level, (i.e. to create new 'bridges' between people and organizations) and the processual level (i.e. to 'bond' the new relationship through nurturing). For small bioscience firms these heightened levels of connectivity allow them to develop both a voice and profile in the community.

\section{Design for diffusion}

The design for diffusion rule conflates the construct 'learning and knowledge transfer' with management practices associated with knowledge management within networked NPD teams. In the bioscience community, scientists are keen to ensure learning is not divorced from practice by confining it to the pursuit of formal qualifications. The implication for managers is to create practice-based learning opportunities within networks to facilitate knowledge transfer and not to limit learning to the traditional realms of the classroom. A key judgment that managers might seek to make is the degree of integration between the various networks that operate at the individual and firm level, to gauge the relative ease by which knowledge can flow through them. This will also assist the identification of further learning opportunities. The following quotation illustrates the potential for learning through networks:

"It dawned on us that we have to invest in developing phenomenal networking capabilities, to help us to learn. The stakes were really high, the top management team had to come in 
agreement and we had to develop this as mission critical to survive." (Head of Drug Discovery, Biotech)

\title{
Design for strategic innovation portfolio
}

The design for strategic innovation portfolio rule conflates the constructs 'embeddedness and complexity', 'openness and security' and 'continuous \& discontinuous renewal' and the management practices associated with coordinating multiple and different networks, some of which are embedded (e.g. one off co-venture agreements nested within a strategic alliance) and serve different purposes. Whilst this situation is indicative of greater levels involvement and openness in R\&D, it also breeds insecurities regarding IPR issues:

\begin{abstract}
"There is public and private research. Public research is publications driven. Within commercial private settings, there is privacy. Scientists are very nervous with their data. They always hold it close to their chest. If you want to apply for a patent for a chemical compound, then this data is a trace of your systematic research. For over 15 years there has been a discussion to let's make this lab journal electronic, but this has not happened. There is a very strong reluctance to publish data." (R\&D Manager, Big Pharma)
\end{abstract}

The implication for managers is to consider their firm's involvement in networks as a strategic portfolio of their collaborative efforts. In doing so, they can begin to distinguish different types of networks (i.e. strategic alliance, learning network, joint venture etc) and their related purpose (i.e. explorative or exploitative) to better manage IP issues (e.g. security, risk and knowledge spill over).

Clearly bioscience firms are evolving their interorganizational networking capabilities in response to the challenges of creating new resources and value as they pursue product development. The authors consider this response within the context of a meta understanding of the industry dynamics and, how they might be strategically managed for achieving future competitive advantage. Therefore, the following section explores the overriding notion of interorganizational innovation from a Dynamic Capabilities View, an increasingly popular theoretical perspective in the field of Strategic Management. In doing so, we seek to complement the implications for managerial practice, as discussed in an earlier section, with a consideration of the implications for strategic management theory.

\section{Discussion: Exploring a Dynamic Capability View}

\section{Network Development Capability}

The last decade has witnessed an upsurge in research seeking to incorporate different strategic management perspectives in the field of operations management and strategy (Gagnon, 1999; Pandza et, al, 2003; Mills et al, 2003; Miller and Ross, 2003). In particular, this work has begun to demonstrate the relevance of the Resource-Based View (RBV) and Dynamic Capability Views (DCV) to improved future research and practice. More recently, Pilkington and Fitzgerald (2006) foresee this shift to become a prominent perspective focussing away from a Porterian paradigm, and more towards a consideration of internal capability development for sustainable competitive advantage. They go on to suggest that studies conducted under this up-and-coming 
wave are 'seeking a more subtle understanding of operations management by considering its practice in relations to strategy, context and resources'. Thus making it a useful theoretical departure point for our research. We hope to advance this emerging discourse by advocating new capabilities to coordinate network development relevant to strategy and operations in competitive global landscapes. In trying to do so, we stress the important role of strategic alignment and some 'synergistic process of integrating business and operations strategic issues' (Anderson et al, 1989) for significant impact on organization performance.

The research findings indicate that the industry dynamics in the burgeoning biopharmaceuticals sector are shifting the locus of knowledge and value creation within the supply chains. The locus is moving away from the firm to being spread over a wider network of heterogeneous firms. This change is becoming a dominant design feature of the industry and signals an urgent need to develop interorganizational networking capability for the purposes of innovation. In this section the authors consider the DCV as a useful theoretical view, derived from the RBV of the firm, to explore an explanation for this relocation of knowledge and value creation (Barney, 1991, Nelson, 1991; Penrose, 1959; Prahalad and Hamel, 1990; Teece et al, 1997). In doing so, the authors highlight the significance of a dynamic capability which addresses the renewal of a network-specific resource base.

The RBV explores the link between internal features of the firm and its performance (Barney, 1991). At the heart of the theory lies the argument that organizations are a bundle of resources, that are simultaneously Valuable, Rare, Imitable and Nonsubstitutional, or in other words 'pass' Barney's VRIN test. Essentially the RBV locates the source of competitive advantage inside the firm and associates rent generation with VRIN qualified resources, controlled by the firm. To briefly summarize, the RBV discusses value creation through alterations in the firm's heterogeneous resource base that is considered to be idiosyncratic and sticky in relation to the firm itself, or in other words 'firm-specific'. Finally, the RBV deals with the business level question of how to compete and is espoused to be a static theoretical perspective, as it considers resources at a specific point in a firm's history (Preim and Butler, 2001).

A relatively recent elaboration of the RBV of the firm, the DCV, addresses the underpinning organizational routines associated with future resource creation. The DCV focuses on the capacity of a firm to renew resource bundles or in other words 'integrate, build and reconfigure internal and external competencies to address changing environments' (Teece et al 1997). Whilst the functionality of such dynamics capabilities is generic, their value lies in the resource configurations they create and not in the capabilities themselves (Eisenhardt and Martin, 2000). In a manner not dissimilar to Henderson and Cockburn (1994) conception of 'architectural competence', this signals a co-evolutionary process in which the interaction of resources, competencies and capabilities within the firm are transformed into competitive advantage.

Major theoretical contributions to both the RB and DC views do not fully develop their discourse at the interorganizational level. Therefore, Cohen and Levinthal's (1989) depiction of the crucial role of knowledge creation through endogenous R\&D efforts and discussion of 'absorptive capacity', combined with the adoption of 
technologies developed by others (outside the firm) for successful innovation, present a significant challenge to the traditional RB and DC view. However, the authors argue there is scope for the RB and DC views to better inform the broader practice of managing innovation in an increasingly multi-player (or network) context. Hagedoorn and Duysters (2002) more recently fortify the DCV by similarly stressing the importance of the efficient use of external resources. Similar sentiments are borne in the light of more recent discussions by Day \& Shoemaker (2006) of how companies develop 'peripheral vision' - a propensity to exercise vigilance over the demands of their environments and so maintain a competitive position. The various contributions of these authors are alluding to the importance of knowledge and value creation being located outside the boundary of the single firm.

Inspired by the DCV the authors propose that, in the context of fast changing biopharmaceuticals environment, the notion of the 'firm' is a distinction that needs to be relaxed and elevated to an 'inter-firm' conceptualisation. Following on from this proposition, the authors suggest that the various connections or relationships between firms in a wider inter-firm network can in themselves amount to being 'network resources' and specific to the network itself. Whilst such resources exist in the spaces between individual firms they still pass the VRIN test, yet are not controlled by any single firm and so present a different category of resource altogether, to that which is articulated by the traditional RBV. In this new category, the control of resources is considered to be distributed within the network. A further distinction from the traditional RBV is that for these resources for many biopharmaceutical firms come with the promise of future rents, rather than actual rents. As Bowman and Ambrosini (2003) indicate 'because the processes of resources creation are not well understood, and because the identification of rent generating resources is problematic, we have to examine the processes of asset creation'. Due to causal ambiguity it is difficult to determine which particular activities if enacted will result in the creation of 'true' resources that fulfil the VRIN tests. Bowman and Ambrosini (2003) go on to suggest that it might be appropriate to investigate the activities and processes that should create assets (non rent generating resources) and may result in new resources (i.e. those that are rent generating).

Therefore in the biopharmaceuticals sector, dynamic capabilities associated with the resource creation (both assets and resources) cannot be simply considered to be 'firm specific', as some are likely to be enacted at higher level, within a wider network at an inter-firm level. Subsequently these capabilities reconfigure assets and resources that are both specific to the firm and specific to the wider network, through an inter play which may allow for certain resources to become more idiosyncratic and perhaps firm-specific over-time. Therefore, the wider network contributes to knowledge and value creation by exhibiting dynamic capabilities. Whether or not the process of new resource creation is triggered reactively or proactively, it may involve processes of coordination, replication, learning and reconfiguration (Teece et al, 1997). In alluding to Bower's (1993) network approach we recognise the possibility of firms accessing resources not simply through direct relationships, but also via third party relationships and contributors to the total resources of the wider network.

With a view to developing the theoretical discourses in the DCV at an inter-firm and network level, the authors highlight the significance of a dynamic capability which addresses the renewal of network connections and relationships (i.e. a resource and 
asset base that is specific to the network) in line with changes to its environment. It is essentially concerned with the network development process (i.e. creation, operation and closure). If we consider Makadok's (2001) argument that dynamic capabilities are built rather than bought in the market, and so embedded in the firm, this dynamic capability is similarly nurtured over time, yet embedded in a wider network. Indeed network connections and relationships are considered to be network-specific assets and resources, that would display path dependencies and so difficult to imitate. The theoretical implications of such a suggestion are that we relax our distinctions of what constitutes the firm and consider the network as a higher order entity that may also possess assets and resources, and so suggest a blurring between firm and network level strategic issues. This reflection inevitably calls into question the idea of 'firmspecificity' in the traditional RB and DC views. The challenging role for the networked firm is the creation of new resource configurations from within a resource base that is controlled in a distributed manner by networked firms. Our propositions amount to dynamic capability that is not simply performed by the single firm, but is enacted and performed at the network level. Our suggestions to some extent corroborate Dyer and Singh (1998) notion of relational capability development.

It seems reasonable to advocate that competitive advantage cannot be manipulated within the boundary of the single firm as assumed by a traditional RB and DC views with their preoccupation with firm-specific resources and capabilities, enacted at the firm level. In the growing biopharmaceuticals industry the locus for innovation is shifting into a broader network of firms, rendering a preoccupation with leveraging network-specific resources and capabilities as worthwhile. Firms recognising they are a 'node' in a network can encourage competitive advantage through the careful renewal of network connections and relationships. Indeed new assemblies and bundles of such network resources could potentially generate the new and unique value.

\section{Conclusions and Further Research}

Relatively novel organizational forms such as networks are being deployed to access new technologies and their associated know-how to improve innovation capacity. Such opportunities to exploit superior external knowledge resources for new product development have become a distinctive feature of the burgeoning biopharmaceuticals industry. Consequently, the prevailing industry dynamics are shifting the locus of knowledge and value creation away from the firm and into the broader enterprise of the network. This poses important questions concerning the nature of resources that reside in the space between firms and how they are leveraged for innovation. Such inquiries are relevant to improving practices associated with operationalizing interorganizational innovation networks, at both the strategic and operations management levels.

This research has deployed van Aken's seminal ideas about generating designoriented knowledge to assist managers in pursuit of the benefits of inter-organization innovation. It reveals 7 empirically and theoretically grounded technological rules associated with the effective inter-organizational networking for innovation, through improved design. They compose vital knowledge which provides solution architecture 
of viable action options for managers a priori, to purposefully design innovation networks. Collectively the rules represent tentative taxonomy, a means of classifying design principles for managers to shape their decision making processes and devise appropriate network development strategies and operations. It also acts as a useful framework for evaluating current managerial practices and considering the range of possibilities available to guide future action. Thus constituting valuable transferable knowledge to support improvements in organizational innovation capacity and performance.

In acknowledging that this research contributes a tentative taxonomy of design rules for practicing managers, we recommend field-testing as an important antecedent to management action. A further limitation of this research is its focus on Biopharmaceuticals sector, and so future investigations to refine the taxonomy should span additional industrial contexts.

Finally, following the recent upsurge in research incorporating different strategic management perspectives in the field of operations management and strategy, we succumb in the same spirit. In seeking to advance this emerging discourse we consider the resource-based and dynamic capability views, and advocate new capabilities to coordinate network development. More specifically, we highlight the significance of a dynamic capability which addresses the renewal of network-specific resources in response to changes in the competitive environment. Unlike dynamic capabilities enacted at the firm level, this one is enacted at a network level.

\section{Acknowledgements}

The authors would like to express their deepest thanks to the Engineering and Physical Sciences Research Council (EPSRC), UK-Biobank and IBM Business Consulting (Life Sciences Division) as the sponsors of this exploratory study. We would also like to thank Professor Chris Lowe (Cambridge University, UK) and Dr Sarah Gurr (Oxford University, UK) for their valuable insights into the UK Biotechnology Industry.

\section{References}

Adler, P. and Kwon, S.-W. (2002). 'Social Capital: Prospects for a New Concept', Academy of Management Review, 27, pp. 17-40.

Anderson, J, C; Cleveland, G and Schroeder, R, G. (1989) 'Operations strategy: a literature review', Journal of Operations Management, Vol 8, Issue 2 ,pp 133-158.

Argyris, C. (1993). Knowledge for Action. San Francisco: Jossey-Bass Publishers

Araujo, L. (1998). 'Knowing and learning as networking', Management Learning, 29, 3, pp. 317-336.

Barney, J. (1991), 'Firm resources and Sustained Competitive Advantage', Journal of Management, 17, pp. 99120.

Barney, J.B. \& Hansen, M.H, (1994). 'Trustworthiness as a source of competitive advantage', Strategic Management Journal, 15, pp. 175-190.

Barney, J.B. (2001). 'Is the resources based 'view' a useful perspective for strategic management research? Yes,' Academy of Management Review, 26(1) pp. 41-56.

Bartlett, C.A. and Ghoshal, S. (2002). 'Building competitive advantage through people', MIT Sloan Management Review, 43 (2), p. 34-41.

Belussi, F. and Arcangeli, F. (1998). 'A typology of networks: flexible and evolutionary firms', Research Policy, 27, pp. 415-428

Bessant, J. 'Managing Innovation: moving beyond the steady state', Inaugural Lecture, Cranfield School of Management, Cranfield University, 2003. 
Bessant, J. (2003), High Involvement Innovation, John Wiley, Chichester.

Bessant, J. and Tsekouras, G. (2001). 'Developing learning networks', AI \& Society', 15, pp. 82-98.

Birkinshaw, J. and Fey, C.F. (2001). 'External Sources of Knowledge and Performance in R\&D Organizations', Working Paper for Academy of Management Journal.

Bolino, M.C., Turnley, W.H. \& Bloodgood, J.M. (2002). 'Citizenship behaviour and the creation of social capital in organizations', Academy of Management Review, 27 (4), pp. 505-522.

Bower, D.J. (1993). 'New product development in the pharmaceutical industry: pooling network resources' Journal of Product Innovation Management, 10, 367-375.

Bowman, C and Ambrosini, V. (2003). How the Resource-based and the Dynamic Capability Views of the Firm Inform Corporate-level Strategy, British Journal of Management. Vol.14, Iss.4; pp289.

Brown S and J Bessant. (2003). The manufacturing strategy-capabilities links in mass customization and agile manufacturing - an exploratory study, International Journal of Operations \& Production Management, Vol 23, No 7, pp 707-730.

Bunge, M. (1967). Scientific Research 2: The Search for Truth, Springer Verlag, Berlin.

Burt, R. (1992). Structural Holes: The Social Structure of Competition. Cambridge, MA: Harvard University Press.

Burt, R.S. (1997). 'The contingent value of social capital', Administrative Science Quarterly, 42, pp. 339-365.

Chesbrough, H.W. (2003). 'The era of open innovation', MIT Sloan Management Review, 44 (3), pp. 35-41.

Coase, R. H. (1937). 'The Nature of the Firm', Economica, 5.

Cohen M. and Levinthal D. (1989). 'Innovation and Learning: The Two Faces of R\&D', Economic Journal, 99, pp. 569-596.

Coleman, J. (1988). 'Social capital in the creation of human capital' American Journal of Sociology, 94, pp. 95120 .

Coleman, J.S. (1990). Foundations of social theory, Cambridge, MA: Belknap Press of Harvard University Press.

Coombs, R. and Metcalfe, J. (2002). 'Innovation in pharmaceuticals: perspectives on the co-ordination, combination and creation of capabilities', Technology Analysis and Strategic Management, 14 (3), pp. 261-272.

Conner, K.R. and Prahalad, C.K. (1996). 'A resource-based theory of the firm: knowledge versus opportunism', Organization Science, 7(5), pp. 477-501.

Cross, R., Borgatti, S.P. and Parker, A. (2002). 'Making invisible work visible: Using social network analysis to support strategic collaboration', California Management Review, 44 (2), pp. 25-46.

D’Aveni, R. (1994). Hypercompetition, The Free Press.

Dyer, J.H., Kale, P. and Singh, H. (2001). 'How to Make Strategic Alliances Work', MIT Sloan Management Review, 42 (4), pp. 37-43.

Dyer, J.H and Singh, H. (1998). 'The relational view: cooperative strategy and sources of interorganizational competitive advantage, The American Academy Review, Vol 23, No. 4, p66-679.

Eisenhardt, K.M. (1989). 'Making fast strategic decisions in high velocity environments', Academy of Management Journal, 32 (3), pp. 543-576.

Eisenhardt, K.M. and Martin, J.A. (2000). 'Dynamics capabilities: what are they?', Strategic Management Journal, 21 (10/11), pp. 1105-1121.

Florida, R., Cushing, R. and Gates, G. (2003). 'When social capital stifles innovation', Harvard Business Review, August, pp. 20.

Foster, J., Bowskill, N., Lally, V. and McConnell. (2002). 'Managing Institutional Change for Networked Learning: A multi-stakeholder approach' in: C. Steeples C. Jones (Eds), Networked Learning; Perspectives and Issues, Springer Verlag.

Frenken, K. (2000). 'A complexity approach to innovation networks. The case of the aircraft industry', Research Policy, 29, pp. 257-272.

Gargiulo, M. and Benassi, M. (2000). 'Trapped in your own net? Network cohesion, structural holes, and the adaptation of social capital', Organization Science, 11 (2), pp. 183-196.

Gagnon S. (1999). Resource-based competition and the new operations strategy. International Journal of Operations \& Production Management, Vol 19, Iss 2, pp 125-136.

George, G., Zahra, S.A. and Wood, D.R. (2002). 'The Effects of Business-University Alliances on Innovative Output and Financial Performance: A Study of Publicly Traded Biotechnology Companies', Journal of Business Venturing, 17 (6), pp. 577-609.

Grandori, A. and Soda, G. (1995). 'Inter-firm networks: antecedents, mechanisms and forms', Organization Studies, 16, pp. 183-214.

Granovetter, M. (1985). 'Economic action and social structure: A theory of embeddedness', American Journal of Sociology, 91, pp. 481-510. 
Gulati, R., Nohria, N. and Zaheer, A. (2000). 'Strategic Networks', Strategic Management Journal, 21, pp. 203215. (2000)

Huff, A. (2000). Changes in Organizational Knowledge Production, Academy of Management Review, 25(2):288-293

Hagedoorn, J. and Duysters, G. (2002). 'External sources of innovative capabilities: the preference for strategic alliances or mergers and acquisitions' Journal of Management Studies, 39, pp. 167-188.

Håkansson, H. (1987). Industrial Technological Development: A Network Approach, Croom Helm, London.

Henderson, R. and Cockburn, I.M. (1994). 'Measuring Competence? Exploring Firm Effects in Pharmaceutical Research', Strategic Management Journal, 15, pp. 63-84.

Kostova, T. and Roth, K. (2003). 'Social capital in multinational corporations and a micro-macro model of its formation', Academy of Management Review, 28(2), pp. 297-317.

Kreiner, K. \& Schultz, N. (1993). 'Informal collaboration in R\&D: The formation of networks across organizations', Organization Studies, 14(2), pp. 189-209.

Liebeskind, J., Porter, O., Zucker, L. and Brewer, M.(1996). ,Social networks learning and flexibility: sourcing scientific knowledge in new biotechnology firms', Organization Science, 7, pp. 428-443.

Lovas, B. and Ghoshal, S. (2000). 'Strategy as guided evolution', Strategic Management Journal, 21(9), pp. 875-896.

Makadok, R. (2001). Toward a synthesis of the resource-based and dynamic-capability views of rent creation. Strategic Management Journal. Chichester: May 2001. Vol. 22, Iss. 5 ; p. 387

Markides, C. and Geroski, P. (2003). 'Teaching elephants to dance and other silly ideas, Business Strategy Review', 14(3), pp. 49-53.

Miles, M. B., \& Huberman, A. M. (1994). Qualitative data analysis, (2nd ed.). Thousand Oaks, CA: SAGE.

Murray, F. (2004). 'The role of academic inventors in entrepreneurial firms: sharing the laboratory life', Research Policy, 33, pp. 643-659.

Mills, J; Platts, K and Bourne M. (2003). Applying resource-based theory: methods, outcomes and utility for managers, International Journal of Operations \& Production Management, Vol 23, No 2, pp 148-166.

Miller S, R and Ross A, D. (2003). An exploratory analysis of resource utilization across organizational units: Understanding the resource-based view, International Journal of Operations \& Production Management, Vol 23, No 9, pp 1062-1083.

Nahapiet, J. \& Ghoshal, S. (1998). 'Social capital, intellectual capital and the organizational advantage', Academy of Management Review, 23(2), pp. 242-266.

Nelson, R. (1991). 'Why Do Firms Differ And How Does It Matter?', StrategicManagement Journal, 12, pp. 61-74.

Newell, S., Tansley, C. and Huang, J. (2004). 'Social Capital and Knowledge Integration in an ERP Project Team: The Importance of Bridging and Bonding', British Journal of Management, 15, S43-S57.

Nowotny, H., Scott, P. and Gibbons, M. (2001). Re-thinking Science. Knowledge and the Public in the Age of Uncertainty. Oxford : Polity Press.

Orsenigo L., Pammolli, F. and Riccaboni, M. (2001). 'Technological Change and Network Dynamics. Lessons from the Pharmaceutical Industry', Research Policy, 30, pp. 485-508.

Owen-Smith, J., Riccaboni, M., Pammolli, F. \& Powell, W.W. (2002). 'A Comparison of U.S. And European University Industry Relations in the Life Sciences', Management Science, 48(1), pp. 24-43.

Owen-Smith, J. and Powell, W.W. (2003). 'The expanding role of university patenting in the life sciences: assessing the importance of experience and connectivity', Research Policy, 32, pp. 1695-1711.

Owen-Smith, J. and Powell, W.W. (2004). 'Knowledge Networks as Channels and Conduits: The Effects of Spillovers in the Boston Biotechnology Community', Organization Science, 15(1), pp. 5-21.

Oliver, A. (2004). 'Biotechnology entrepreneurial scientists and their collaborations', Research Policy, 33(4), pp. 583-597.

Oliver, A.L. and Liebeskind, J. (1997). 'Three levels of networking for sourcing intellectual capital in biotechnology: implications for studying interorganizational networks', International Studies of Management and Organization, 27(4), pp. 76-103.

O'Reilly III, C.A. and Tushman, M.L. (2004). 'The Ambidextrous Organization', Harvard Business Review, 82 (4), pp. 74-81.

Pandza, K; Polajnar, A and Buchmeister. (2003). Evolutionary perspectives on the capability accumulation process. International Journal of Operations \& Production Management, Vol 23, No 8, pp 822-849

Penrose, E. (1959). The theory of the growth of the firm, London, Basil Blackwell.

Pettigrew, A.M. (2001). 'Management Research after Modernism'. British Journal of Management 12, pp S61S70.

Pilkington, A and Fitzgerald. (2006). Operations management themes, concepts and relationships: a forward retrospective of IJOPM, International Journal of Operations \& Production Management, Vol 26, No 11 , pp 1255-1275. 
Pittaway, L., Robertson, M., Munir, K., Denyer, D. and Neely, A. (2004). 'Networking and innovation: a systematic review of the evidence', International Journal of Management Reviews, 5/6 (3\&4), pp. 137168.

Powell, W. (1998). 'Knowledge and networks in the biotechnology and pharmaceutical industries', California Management Review, 40(3), pp. 228-240.

Powell, W.W Koput, K.W and Smith-Doerr, L.(1996). 'Interorganizational collaboration and the locus of innovation: networks of learning in biotechnology', Administrative Science Quarterly, 41(1), pp. 116145.

Pisano, G.P. (1997). The Development Factory: Unlocking the Potential of Process Innovation, Cambridge, MA: Harvard Business School Press.

Preim R L and Butler J E (2001), Is the resources based 'view' a useful perspective for strategic management research? Academy of Management Review, Vol 26 No 1 p22-40

Prahalad C.K., Hamel G. (1990), The core competencies of the corporation, Harvard BusinessReview, MayJune, 79-91.

Prusak, L. and Cohen, D. (2001). 'How to invest in social capital', Harvard Business Review, June, pp. 86-93.

Prusak, L and Lesser, E. (1999). 'Communities of practice, social capital and organizational knowledge', Information Systems Review, 1(1), 3-9.

Pyka, A. (2002). 'Innovation networks in economics: From the incentive-based to the knowledge-based approaches', European Journal of Innovation Management, 5(3), pp. 152-163.

Pyka, A. and Saviotti, P. (2001). 'Innovation networks in the biotechnology based sectors', available at http://www.wiwi.uni-augsburg.de/vwl/institut/paper/205.pdf (Accessed June, 2004).

Rumelt, R.P. (1972). 'Diversification strategy and profitability'. Strategic Management Journal, 3, pp 359-370.

Rothwell, R. (1992). 'Successful Industrial Innovation: Critical Factors for the 1990s', R\&D Management, 22(3), pp. 221-239.

Smart, P., Brookes, N., Lettice, F., Backhouse, C. \& Burns, N. (2002). A Boundary Based View of Product Development: A Feasibility Study. IMecheE, Journal of Engineering Manufacture, Proceedings Part B, Vol 216,pp1-12

Starkey, K. and Madan, P. (2001). Bridging the Relevance Gap: Aligning Stakeholders in the Future of Management Research. British Journal of Management, 12, pp S3-S26.

Stevenson, W.B. and Greenberg, D. (2000). 'Agency and social networks: Strategies of action in a social structure of position, opposition and opportunity', Administrative Science Quarterly, 45(4), pp. 651678.

Swan, J., Newell, S., Bresnen, M., Mendes, M., Perkmann, M. and Robertson, M. (2005). 'Exploring interactivity in biomedical innovation : a framework and case study analysis', Proceedings of the Organizational knowledge, Learning and Capabilities Conference, Boston.

Swan, J., Scarbrough, H. and Robertson, M. (2002). 'The construction of communities of practice in the management of innovation', Management Learning, 33, 4, 2002, pp. 477-496.

Teece, D.J., Pisano, G.P. and Schuen, A. (1997). 'Dynamic Capabilities and Strategic Management', Strategic Management Journal, 18(7), pp. 509-533.

Tidd, J. (1997). 'Complexity, Networks and Learning: Integrative Themes for Research on the Management of Innovation', International Journal of Innovation Management, 1(1), pp. 1-19.

Tranfield, D. and Starkey, K. (1998). 'The nature, social organization and promotion of management research: Towards policy'. British Journal of Management, 9, pp 341-353.

Tranfield, D., Denyer, D. and Smart, P. (2003). 'Towards a methodology for developing evidence-informed management knowledge by means of a systematic review', British Journal of Management, 14(3), pp. 207-222.

Tushman, M.L. and O'Reilly III, C.A. (1996). 'Ambidextrous Organizations: Managing Evolutionary and Revolutionary Change', California Management Review, 38(4), pp. 8-30.

Uzzi, B. and Lancaster, R. (2003). Relational embeddedness and learning: The case of bank loan managers and their clients, Management Science, 49 (4), pp. 383-399.

Van Aken, J.E. (2005). 'Management Research as a Design Science: Articulating the Research Products of Mode 2 Knowledge Production in Management', British Journal of Management, 16(1), pp. 19-36.

Watson, J. D. and Crick, F. H. C. (1953). 'Molecular structure of Nucleic Acids', Nature, 171, pp. 737-738.

Williamson, O. E. (1975). Markets and Hierarchies, The Free Press, New York.

Yin, R.K. (1994). Case Study Research: Design and Methods (2nd ed.), Thousand Oaks, Sage.

Yli-Renko, H., Autio, E. and Sapienza, H.J. (2001). 'Social capital, knowledge acquisitions, and knowledge exploitation in young technology based firms', Strategic Management Journal, 22(6/7), pp. 587-613.

Zahra, S.A. and Nielsen, A.P. (2002). 'Sources of capabilities, integration and technology commercialization', Strategic Management Journal, 23(5), pp. 377-398. 


\section{Appendix 1}

Table 4: Scatter plot of Emerging Themes

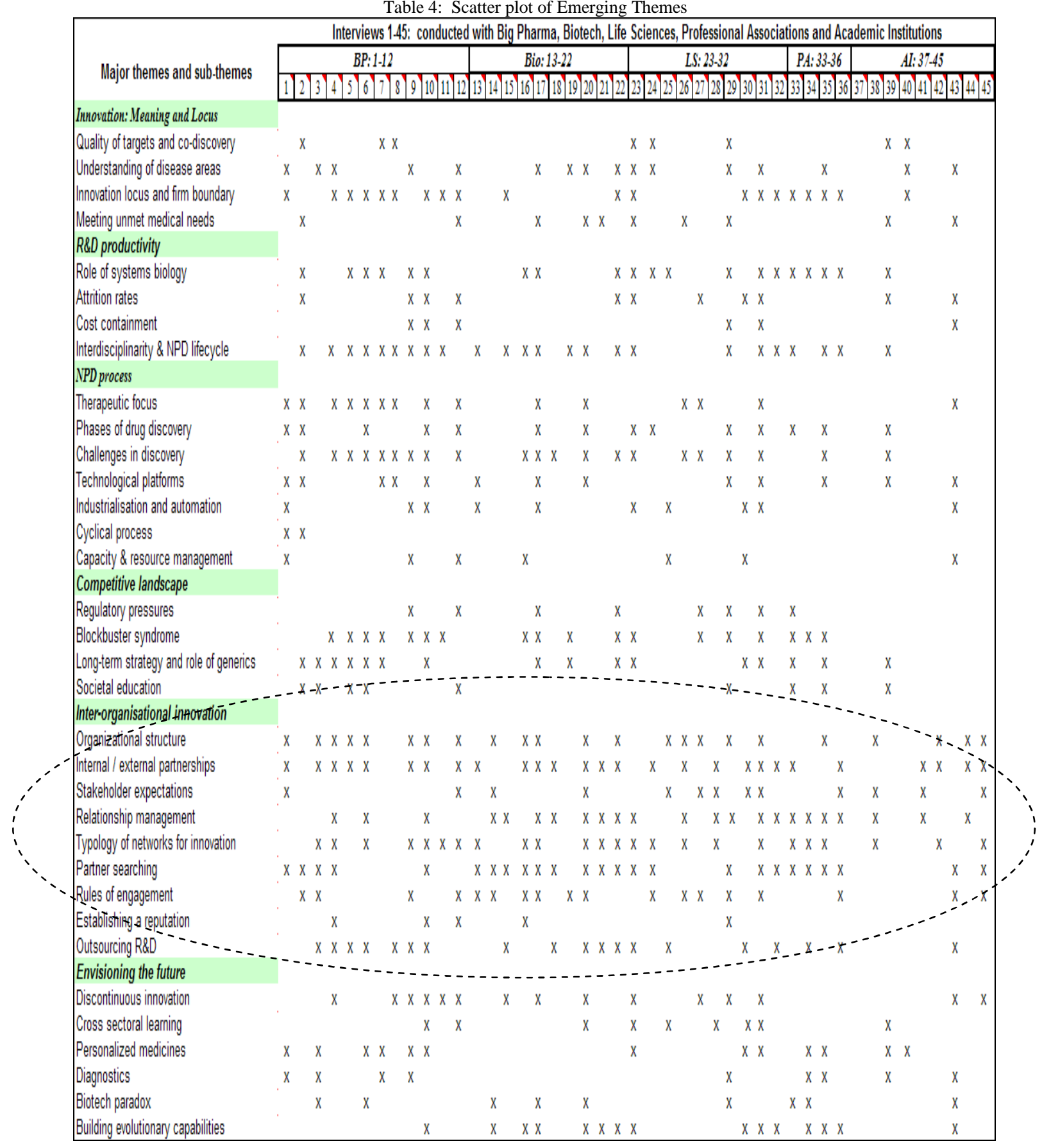

